\title{
Treatment of the Basic Yellow 2 Dyestuff with Fenton Advanced Oxidation Process
}

\author{
Serkan Bayar (Corresponding author) \\ Ataturk University, Faculty of Engineering, \\ Department of Environmental Engineering, 25240 Erzurum, Turkey \\ E-mail: sbayar@atauni.edu.tr; \\ Mahmut Erdogan \\ Ataturk University, Faculty of Engineering, \\ Department of Environmental Engineering, 25240 Erzurum, Turkey \\ E-mail: emahmut56@gmail.edu.tr
}

\begin{abstract}
In this study, the removal of Basic Yellow 2 (BY2) dyestuff used in textile dyeing industry by Fenton process which is one of the Advanced Oxidation Processes (IOP) was investigated. Effect of $\mathrm{pH}, \mathrm{Fe}^{2+}$, hydrogen peroxide $\left(\mathrm{H}_{2} \mathrm{O}_{2}\right)$ and temperature was evaluated on oxidation process. Removal of the colorant (BY2) was monitored by considering color and Chemical Oxygen Demand (COD). A COD removal efficiency of $62.05 \%$ and color of $90.71 \%$ were obtained under optimum experimental conditions where baseline solution $\mathrm{pH}$ is 3 , the concentration of (BY2) colorant is $200 \mathrm{mgL}^{-1}$, rates of $\mathrm{Fe}^{2+}$ and $\mathrm{H}_{2} \mathrm{O}_{2}$ are $150 \mathrm{mgL}^{-1}$ and $400 \mathrm{mgL}^{-1}$, reaction temperature is $20^{\circ} \mathrm{C}$ and experiment time is $30 \mathrm{~min}$.
\end{abstract}

Keywords: Fenton, Basic Yellow 2, $\mathrm{H}_{2} \mathrm{O}_{2}$, pH

DOI: $10.7176 / \mathrm{JSTR} / 5-2-45$

\section{Özet}

Bu çalı̧̧mada tekstil boyama endüstrisinde kullanılan Basic Yellow 2 (BY2) boyar maddesinin İleri Oksidasyon Proseslerinden (IOP) biri olan Fenton prosesi ile giderimi araştırılmıştır. Proseste $\mathrm{pH}, \mathrm{Fe}^{+2}$, hidrojen peroksit $\left(\mathrm{H}_{2} \mathrm{O}_{2}\right)$ ve sıcaklığın etkisi incelenmiştir. (BY2) boyar maddesinin giderimi renk ve Kimyasal Oksijen İhtiyacı (KOİ) üzerinden izlenmiştir. Optimizasyon çalışmaları sonucunda başlangıç çözelti $\mathrm{pH}=3$, (BY2) boyar maddesi konsantrasyonu $=200 \mathrm{mgL}^{-1}, \mathrm{Fe}^{+2}$ konsantrasyonu $=150 \mathrm{mgL}^{-1}$, $\mathrm{H}_{2} \mathrm{O}_{2}=400 \mathrm{mgL}^{-1}$, çözelti sıcaklığ $120^{\circ} \mathrm{C}$ ve reaksiyon süresi 30 dakika olarak belirlenmiştir. Bu şartlar altında renk ve KOİ giderim verimi sırasıyla $\% 90,71$ ve 62,05 olarak bulunmuştur

Anahtar Kelimeler: Fenton, Basic Yellow 2, $\mathrm{H}_{2} \mathrm{O}_{2}, \mathrm{pH}$

\section{Introduction}

With the increase in industrialization, environmental pollution has started to increase considerably. Waste from air, soil and water from different industrial establishments disrupts the natural balance and adversely affects the living organisms and ecosystem. The population growth throughout the world has contributed to the growth of the textile industry, and has made it a sector serving in many branches ranging from clothing to home textiles with different product and color options. One of these industry organizations is the textile industry and has a significant share in the economy of both developed and developing countries. Dyestuffs are contaminants that are resistant to biological degradation. Dyestuffs are mainly used in many industries such as cosmetics, plastics, paints, leather, paper, especially in textile industry. Colorful wastewaters released from the different processes of these industries, when given to natural water environments, disrupt the ecological balance by preventing photosynthesis because they reduce light transmission beyond aesthetic pollution. At the same time the textile industry wastewater contains high color and chemical oxygen demand (COD). 


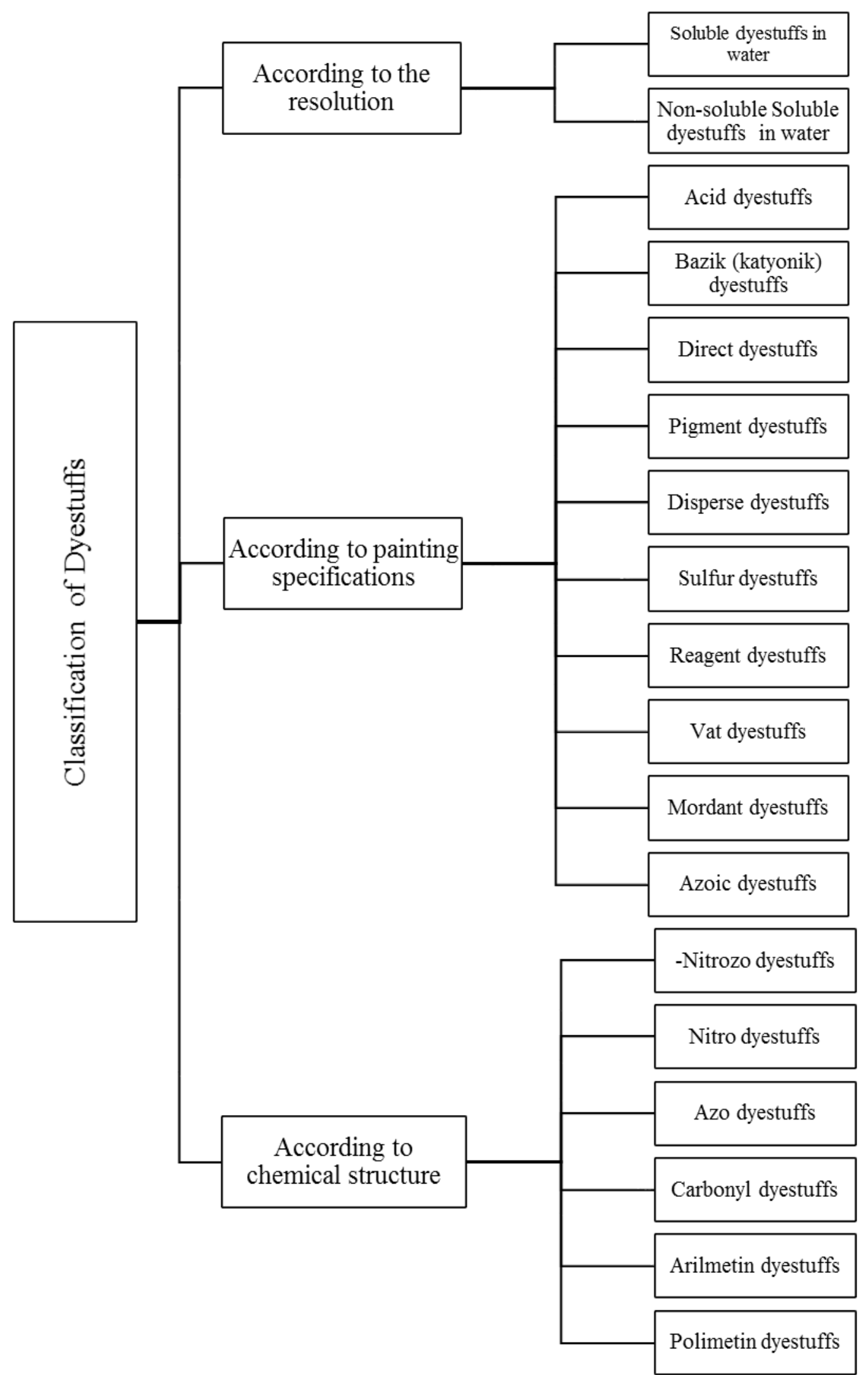

Figure 1. Classification of Dyestuffs (Ertugay, 2012) 
The pollutants in these wastewaters are very difficult and resistant compounds in natural environment and also have carcinogenic and toxic effects. For this reason, it is extremely dangerous to give these wastewater to any natural environment without treatment. Figure 1 below gives the classification of dyestuffs.

Recently, Advanced oxidation processes known as environmentally friendly, have been used in the treatment of biologically difficult to degrade waste water. Advanced oxidation processes are based on the formation of hydroxyl radicals with high electrochemical oxidation potential. Hydroxyl radicals are not selective and react with all organic substances and form the end product $\mathrm{CO}_{2}$ and $\mathrm{H}_{2} \mathrm{O}$. The Fenton process is based on the reaction of $\mathrm{Fe}^{+2}$ ion with hydrogen peroxide under acidic conditions. Hydroxyl radicals are formed by this reaction. The iron ion initiates the decomposition of $\mathrm{H}_{2} \mathrm{O}_{2}$, catalysis and hydroxyl radicals occur. The formation of hydroxyl radicals is in the form of a complex reaction chain in aqueous solutions. Fenton oxidation process steps are as follows (Bayhan and Değermenci 2017);

$$
\begin{aligned}
& \mathrm{Fe}^{+2}+\mathrm{H}_{2} \mathrm{O}_{2} \rightarrow \mathrm{Fe}^{+3}+\mathrm{OH}^{\bullet}+\mathrm{OH}^{-} \\
& \mathrm{Fe}^{+3}+\mathrm{H}_{2} \mathrm{O}_{2} \rightarrow \mathrm{Fe}^{+2}+\mathrm{HO}_{2}^{\bullet}+\mathrm{H}^{+}
\end{aligned}
$$

All in all, the Fenton process consists of four steps. These are $\mathrm{pH}$ adjusting, oxidation reactions, neutralization process and finally, the process of precipitation with coagulation.

In this study, color and COD removal from synthetic textile wastewaters prepared with Basic Yellow 2 (BY2) dye were investigated with Fenton process. In experimental studies, the effects of $\mathrm{pH}, \mathrm{Fe}^{2+}$ concentration, $\mathrm{H}_{2} \mathrm{O}_{2}$ concentration, initial dye concentration and temperature parameters were investigated.

\section{Materials and Methods}

The dyestuff used in this study (BY2) was obtained from Duraner Boya A.Ş. Molecular formula $\left(\mathrm{C}_{17} \mathrm{H}_{22} \mathrm{ClN}_{3}\right)$ and molecular weight of BY2 dystuff are 303.83 g.mol ${ }^{-1}$. The maximum absorbance wavelength $\left(\lambda_{\max }\right)$ of BY2 dyestuff was $430 \mathrm{~nm}$. The molecular structure of the dyestuff (BY2) is given in Figure 2. Firstly, pH was adjusted by adding dilute $\mathrm{H}_{2} \mathrm{SO}_{4}$ and $\mathrm{NaOH}$ in Fenton process experiments. Following this stage, $\mathrm{FeSO} 4.7 \mathrm{H} 2 \mathrm{O}$ or $\mathrm{FeCl} 3.6 \mathrm{H} 2 \mathrm{O}$ and $\mathrm{H} 2 \mathrm{O} 2$ were added and stirred fast for $3 \mathrm{~min}$ at $150 \mathrm{rpm}$ and then slowly for $27 \mathrm{~min}$ at $50 \mathrm{rpm}$ and the resultant mixture was filtered through $0.45 \mu \mathrm{m}$ membrane filter. Color measurements for (BY2) dyestuff were performed spectrophotometrically at a wavelength of $430 \mathrm{~nm}$. COD analyzes were performed spectrophotometrically at $148{ }^{\circ} \mathrm{C}$ according to the Standard Methods in Merck Spectroquant TR320 at $600 \mathrm{~nm}$ (APHA, 1985).

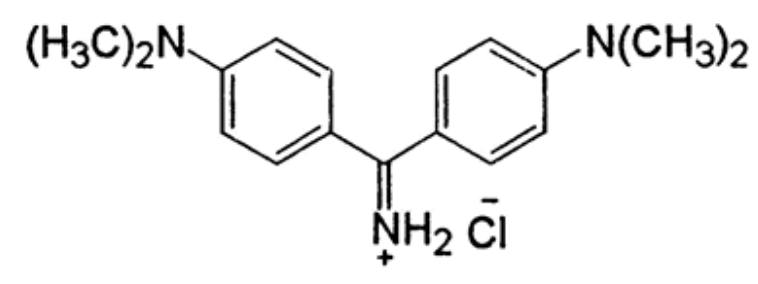

Figure 2. Molecular structure of (BY2).

\section{Results and discussion \\ 3.1. Effect of $\mathrm{Fe}^{2+}$ dosage}

The concentration of the Fenton reagent plays an important role in the degradation of organic substances in the Fenton process. Generally, as the dosage of $\mathrm{Fe}^{2+}$ increases, the rate of degradation of organic substances increases. However, the very large increase in $\mathrm{Fe}^{+2}$ ion leads to an increase in the amount of total dissolved iron ions resulting in sludge formation in the solution. Therefore, it is necessary to avoid excessive sludge formation. Firstly, the effect of $\mathrm{Fe}^{2+}$ dosage was examined in Fenton process. The effect of $\mathrm{Fe}^{2+}$ dosage on color and COD removal efficiency was investigated in 100, 150, 200, 250 and $300 \mathrm{mg}$ $\mathrm{L}^{-1}$ concentrations and the results are shown graphically in Figure 3. Experiments were performed at $\mathrm{pH}$ : 3 , temperature at $20^{\circ} \mathrm{C}$ and at $\mathrm{H}_{2} \mathrm{O}_{2}=500 \mathrm{mgL}^{-1}$. As can be seen from Figure 3, the highest color and COD 
removal efficiencies were obtained as $88.75 \%$ color and $61.42 \%$ COD removal efficiency at $150 \mathrm{mgL}^{-1}$ $\mathrm{Fe}^{2+}$ concentration.

Since there is no basic factor to produce hydroxyl radical in the medium in the absence of $\mathrm{Fe}^{2+}$, an effective oxidation does not occur based on the fenton reaction. As the $\mathrm{Fe}^{2+}$ concentration increases, theoretically more $\mathrm{OH}^{\bullet}$ radicals will be produced. Therefore, when $\mathrm{Fe}^{+2}$ concentration increased from $100 \mathrm{mgL}^{-1}$ to $150 \mathrm{mgL}^{-1}$, the color removal efficiency increased from $80.80 \%$ to $88.75 \%$, while COD removal efficiency increased from $48.6 \%$ to $58.66 \%$. In the experiments above $150 \mathrm{mgL}^{-1} \mathrm{Fe}^{2+}$ concentration, decreasing of both COD and color removal efficiencies were seen. This situation is thought that excess $\mathrm{Fe}^{2+}$ concentration effected negatively of the oxidation capacity. High concentrations of $\mathrm{Fe}^{2+}$ are known to cause consumption of $\mathrm{OH}^{\bullet}$ radicals in the medium (radical scavenging effect) and consequently decrease in removal efficiency (Xu et al. 2004; Chacon et al. 2006; Kaykıoğlu and Debik 2006; Primo and 2008).

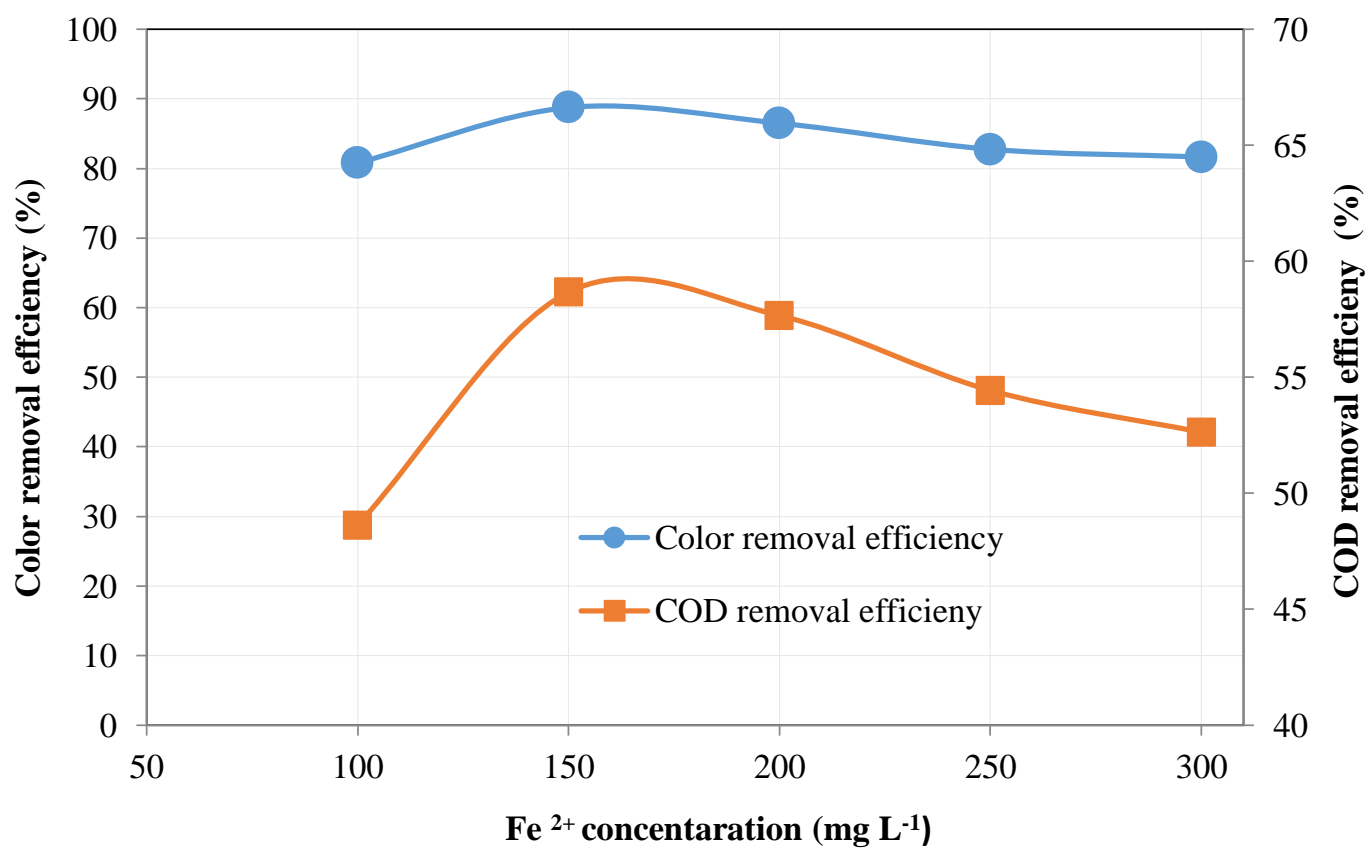

Figure 3. Effect of $\mathrm{Fe}^{2+}$ concentration on color and $\mathrm{COD}$ removal efficiency in fenton oxidation $\left(\mathrm{C}_{0}=200 \mathrm{mgL}^{-1}, \mathrm{H}_{2} \mathrm{O}_{2}=400 \mathrm{mg} \mathrm{L}^{-1}, \mathrm{pH}=3, \mathrm{~T}=20^{0} \mathrm{C}, \mathrm{t}=30 \mathrm{~min}\right.$. $)$

\subsection{Effect of $\mathrm{H}_{2} \mathrm{O}_{2}$ dosage}

One of the important parameters in the Fenton process is the $\mathrm{H}_{2} \mathrm{O}_{2}$ concentration. The determination of the optimum $\mathrm{H}_{2} \mathrm{O}_{2}$ concentration in Fenton processes is important both for the treatment efficiency of the process and for the applicability of the process due to the cost of $\mathrm{H}_{2} \mathrm{O}_{2}$. The effect of $\mathrm{H}_{2} \mathrm{O}_{2}$ concentration was investigated in 6 different values ranging from $100 \mathrm{mg} \mathrm{L}^{-1}$ to $600 \mathrm{mg} \mathrm{L}^{-1}$. In the experiment; $\mathrm{C}_{0}=200$ $\mathrm{mg} \mathrm{L}^{-1}, \mathrm{Fe}^{2+}=150 \mathrm{mgL}^{-1}, \mathrm{pH}=3$ and $\mathrm{T}=20^{\circ} \mathrm{C}$ were kept constant. The results obtained from the experiments are shown in Figure 4.

When Figure 4 was examined, at the end of the 30 min. experiment period with the increasing $\mathrm{H}_{2} \mathrm{O}_{2}$ concentrations from $100 \mathrm{mgL}^{-1}$ to $400 \mathrm{mgL}^{-1}$ resulted in an increase in both color and COD removal efficiencies. Color and COD removal efficiencies were $90.71 \%$ and $62.04 \%$ at $400 \mathrm{mgL}^{-1} \mathrm{H}_{2} \mathrm{O}_{2}$ concentration, respectively. When $\mathrm{H}_{2} \mathrm{O}_{2}$ concentration increased from $400 \mathrm{mgL}^{-1}$ to $500 \mathrm{mgL}^{-1}$, color and COD removal efficiencies decreased to $83.67 \%$ and $38.50 \%$, respectively.

Generally, an increase in the concentration of $\mathrm{H}_{2} \mathrm{O}_{2}$ causes an increase in the rate of degratation of pollutants. (Kang ve Hwang 2000; Sun vd. 2009; Fan vd. 2013; Zhang vd. 2014). In Fenton process, is important to determine the appropriate $\mathrm{H}_{2} \mathrm{O}_{2}$ dosage. Because the excess amount of $\mathrm{H}_{2} \mathrm{O}_{2}$ in the fenton processes will be a positive interference for COD, excessive amount of $\mathrm{H}_{2} \mathrm{O}_{2}$ is not recommended (Mofrad vd. 2015). Another negative effect of excessive amount $\mathrm{H}_{2} \mathrm{O}_{2}$ concentration is the radical

417 | P a g e

www.iiste.org 
scavenging effect on the $\mathrm{OH}^{\bullet}$ radicals produced as in the $\mathrm{Fe}^{+2}$ concentration.(Bouasla et al. 2010; Latif et al. 2015; Ertugay and Acar 2017; Bayhan and Değermenci 2017). At the end of the experiments, the optimum $\mathrm{H}_{2} \mathrm{O}_{2}$ concentration was determined as $400 \mathrm{mgL}^{-1}$ considering both the removal efficiencies and the cost of $\mathrm{H}_{2} \mathrm{O}_{2}$.

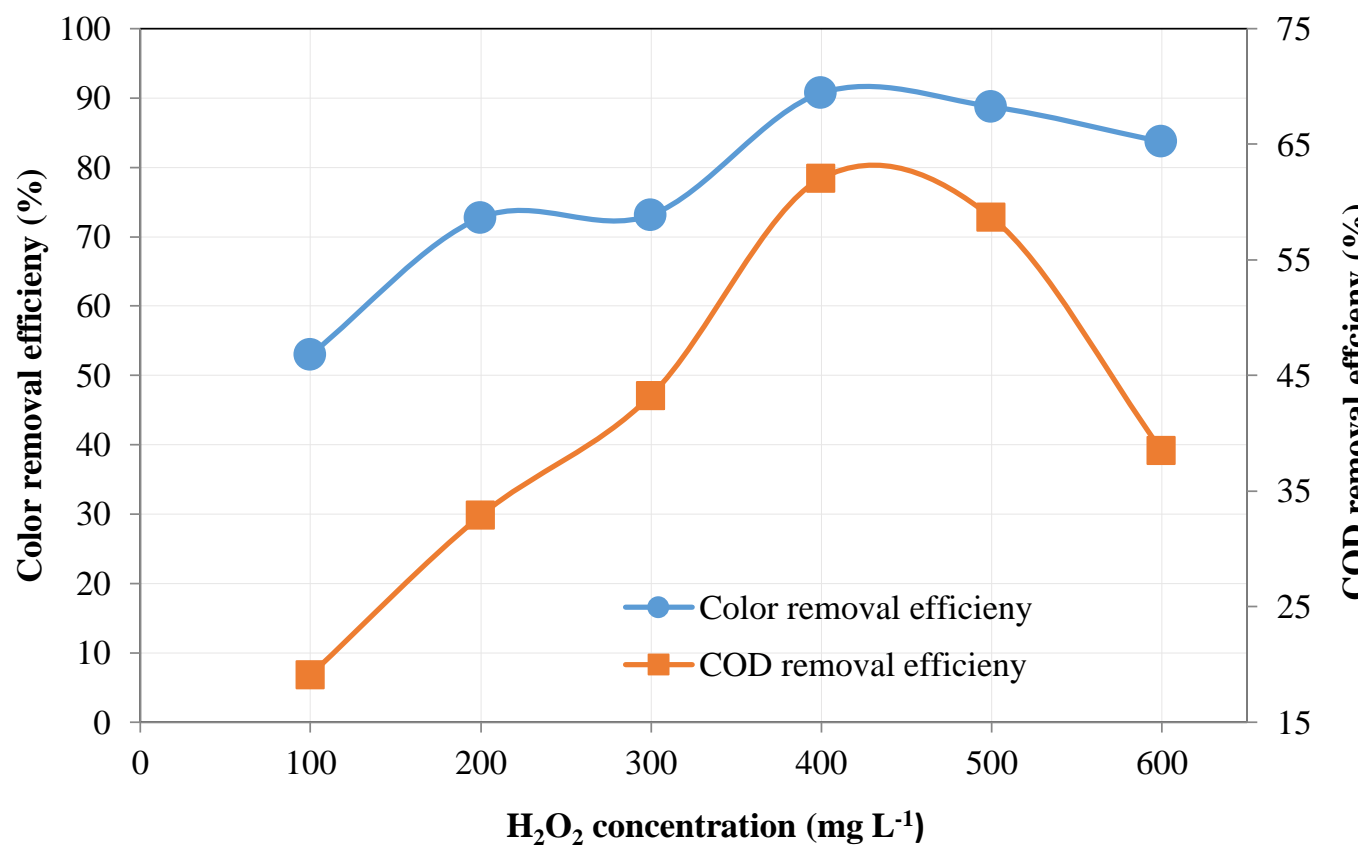

Figure 4. Effect of $\mathrm{H}_{2} \mathrm{O}_{2}$ concentration on color and COD removal efficiency in fenton oxidation $\left(\mathrm{C}_{0}=200 \mathrm{mgL}^{-1}, \mathrm{Fe}^{2+}=150 \mathrm{mgL}^{-1}, \mathrm{pH}=3, \mathrm{~T}=20^{0} \mathrm{C}, \mathrm{t}=30 \mathrm{~min}\right.$. $)$

\subsection{Effect of $\mathrm{pH}$}

Due to the relationship between the oxidation potential and the $\mathrm{pH}$, the $\mathrm{pH}$ value has a decisive effect on the oxidation potential of $\mathrm{OH}^{\bullet}$ radical. In Fenton reactions, organic compounds with $\mathrm{OH}^{\bullet}$ radicals can react rapidly in acidic medium. Therefore, $\mathrm{pH}$ value is important for the formation of $\mathrm{OH}^{\bullet}$ radicals which affect the treatment efficiency. In the Fenton oxidation process, the most effective $\mathrm{pH}$ values are generally in the narrow range of 2.5 and 4, the highest treatment efficiency are generally obtained at $\mathrm{pH}$ 3 in the literatüre (Swamkar et al. 2015). The effect of $\mathrm{pH}$ was investigated in the range of $\mathrm{pH}(2.5-5.0)$. In the experiments, the temperature was kept constant at $\mathrm{T}=25^{0} \mathrm{C}, \mathrm{C}_{0}=200 \mathrm{mgL}^{-1}, \mathrm{Fe}^{2+}=150 \mathrm{mgL}^{-1}$ and $\mathrm{H}_{2} \mathrm{O}_{2}=400 \mathrm{mgL}^{-1}$.

The results are shown graphically in Figure 5. In Figure 5, the highest removal efficiencies are $90.77 \%$ and $62.02 \%$ for color and COD, respectively at the end of 30 - minute experiment time with a pH initial value of 3. Color and COD removal efficiencies decreased in experiments performed above and below $\mathrm{pH} 3$.

When $\mathrm{pH}$ is below 3 , since complex iron types reacting with $\mathrm{H}_{2} \mathrm{O}_{2}$ slower are formed, down and in that case oxidation removals also decrease. Production of $\mathrm{OH}^{\bullet}$ radical decreases since precipitating $\mathrm{Fe}(\mathrm{OH})_{3}$ is formed when $\mathrm{pH}$ is above 3 and as a result, the removal efficiency decreases (Bouasla et al. 2010). 


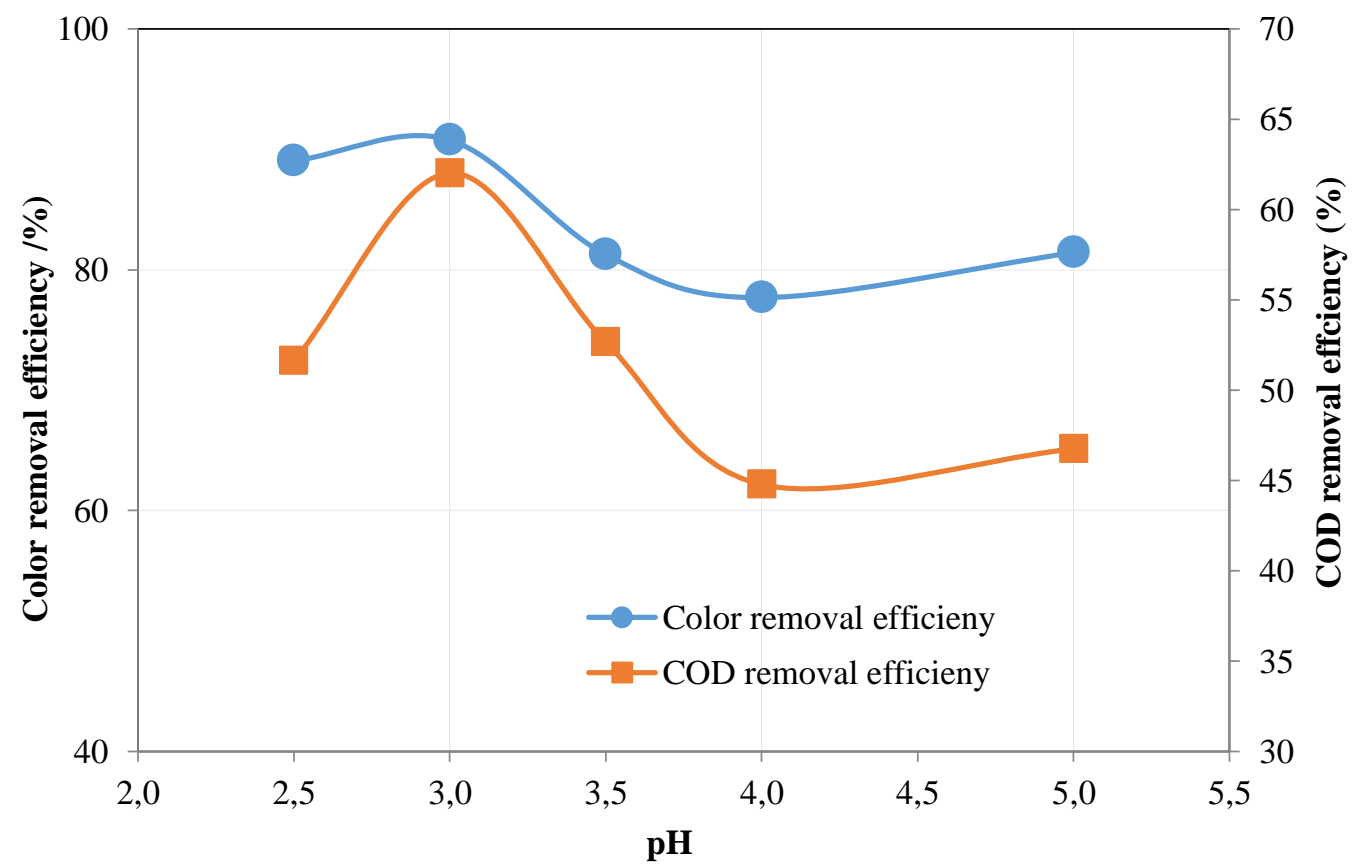

Figure 5. Effect of $\mathrm{pH}$ concentration on color and $\mathrm{COD}$ removal efficiency in fenton oxidation $\left(\mathrm{C}_{0}=200 \mathrm{mgL}^{-1}, \mathrm{H}_{2} \mathrm{O}_{2}=400 \mathrm{mgL}^{-1}, \mathrm{Fe}^{2+}=150 \mathrm{mgL}^{-1}, \mathrm{~T}=20^{0} \mathrm{C}, \mathrm{t}=30 \mathrm{~min}\right)$

\subsection{Effect of temperature}

The effect of temperature in the experiments was examined in the range of $20-60{ }^{\circ} \mathrm{C}$. Experiments were conducted under the conditions, where $\mathrm{pH}$ is $3, \mathrm{H}_{2} \mathrm{O}_{2}$ is $400 \mathrm{mgL}^{-1}$, T is $30 \mathrm{~min}$ and $\mathrm{Fe}^{2+}$ is $150 \mathrm{mg} \mathrm{L}^{-1}$. The data obtained are shown graphically in Figure 6. As seen in Figure 6, no significant change in color and COD removal was observed in all temperature experiment. The color removal efficiencies were between $87,53 \%$ and $89,94 \%$ and the COD removal efficiencies were between $61,62 \%$ and $63,76 \%$.

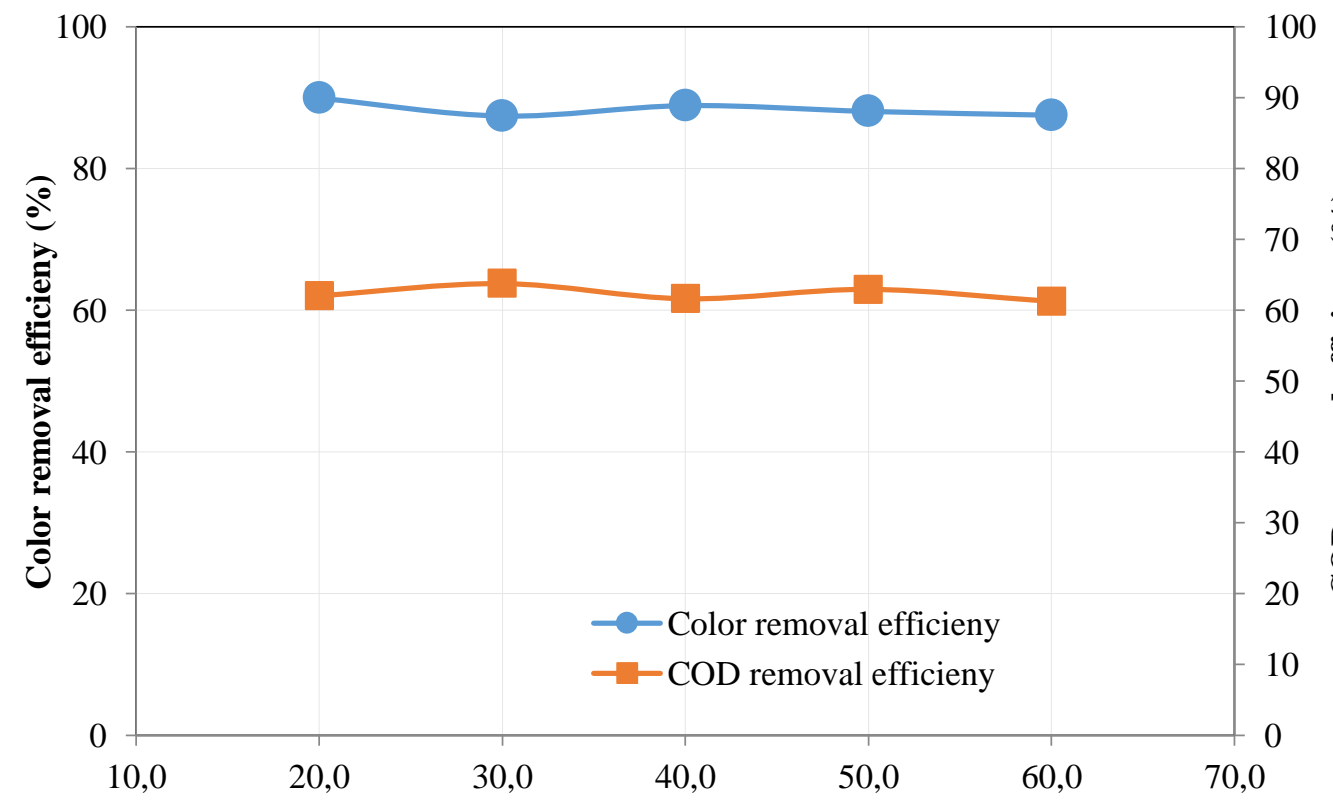

Temperature $\left({ }^{\circ} \mathbf{C}\right)$

Figure 6. Effect of temperature on color and COD removal efficiency in fenton oxidation $\left(\mathrm{C}_{0}=200 \mathrm{mg}\right.$ $\mathrm{L}^{-1}, \mathrm{H}_{2} \mathrm{O}_{2}=400 \mathrm{mg} \mathrm{L}^{-1}, \mathrm{Fe}^{+2}=150 \mathrm{mg} \mathrm{L}^{-1}, \mathrm{pH}=3$, $\mathrm{t}=30$ min.) 


\section{Conclusion}

In this study, the degradability of reactive BY2 dyestuffs by Fenton oxidation process which is one of the advanced oxidation processes (IOP) was investigated. The degradability of the dyestuff (BY2) was evaluated by color and COD parameters. Trials were performed within 30 minutes. The amount of $\mathrm{Fe}^{2+}$ $\left(25,50,75,100,125,150\right.$ and $\left.200 \mathrm{mg} \mathrm{L}^{-1}\right), \mathrm{H}_{2} \mathrm{O}_{2}$ amount $(100,200,300,400,500$ and 600), $\mathrm{pH}(2.5 ; 3$; $3.5 ; 4$ and 5), the concentration of dyestuffs $\left(150,200,250,300,350\right.$ and $\left.500 \mathrm{mgL}^{-1}\right)$ and the temperature $\left(20,30,40,50\right.$ and $\left.60{ }^{\circ} \mathrm{C}\right)$. Optimum conditions in the study were determined to be as follows: $\mathrm{pH}=3$, $\mathrm{C}_{0}=200 \mathrm{mg} \mathrm{L}^{-1}, 150 \mathrm{mg} \mathrm{L}^{-1} \mathrm{Fe}^{2+}, 400 \mathrm{mg} \mathrm{L}^{-1} \mathrm{H}_{2} \mathrm{O}_{2}, 20^{0} \mathrm{C}$ temperature and 30 min of reaction time. Under these conditions, color and COD removal efficiencies were $90.71 \%$ and $62.04 \%$, respectively. As the result of this study, it can be suggested that Fenton oxidation is an effective treatment alternative for BY2 dystuff.

\section{References}

APHA, (1985). AWWA and WPCF. Standart Methods for the Examination of Water and Wastwater, Sixteenth ed. Washington, DC. pp. 76-538.

Bayhan, Y.K.,\& Değermenci, G.D. (2017). Kozmetik Atık Sularından Fenton Prosesiyle Organik Madde Gideriminin ve Kinetiğinin Incelenmesi. J Fac Eng Archit Gaz 32, 8.

Bouasla, C., Samar, M.E.H., Ismail, F. (2010). Degradation of Methyl Violet $6 b$ Dye by the Fenton Process. Desalination 254, 35-41.

Chacón, J.M., Leal, M.T., Sánchez, M., Bandala, E.R. (2006). Solar Photocatalytic Degradation of Azo-Dyes by Photo-Fenton Process. Dyes Pigm 69, 144-150.

Ertugay, N. (2012). Homojen ve Heterojen İleri Oksidasyon Sistemleri İle Boyar Madde Giderimi. Doktora Tezi, Atatürk Üniversitesi Fen Bilimleri Enstitüsü Çevre Mühendisliği Anabilim Dalı, Erzurum.

Ertugay, N., \& Acar, F.N. (2017). Removal of Cod and Color from Direct Blue 71 Azo Dye Wastewater by Fenton's Oxidation: Kinetic Study. Arabian J Chem 10, S1158-S1163.

Fan, C., Horng, C.Y., Li, S.J. (2013). Structural Characterization of Natural Organic Matter and Its Impact on Methomyl Removal Efficiency in Fenton Process. Chemosphere 93, 178-183.

Harber, F., \& Weiss, J. (1934). The Catalytic Decomposition of Hydrogen Peroxide by Iron Salts, Proceedings of the Royal Society of London. Series A - Mathematical and Physical Sciences 147, 332-351.

Kang, Y.W., \& Hwang, K.Y. (2000). Effects of Reaction Conditions on the Oxidation Efficiency in the Fenton Process. Water Res 34, 2786-2790.

Kayıkooğlu, G., \& Debik, E. (2006). Color Removal from Textile Wastewater with Anaerobic Treatment Process. J Eng Nat Sci 4, 10.

Latif, M.I., Qazi, M.A., Khan, H., Ahmad, N., Khan, N.I., Mahmood, K. (2015). Physiochemical Treatment of Textile Industry Effluents. J Chem Soc Pakistan 37, 7.

Mofrad, M.R., Nezhad, M.E., Akbari, H., Atharizade, M., Miranzadeh, M.B. (2015). Evaluation of Efficacy of Advanced Oxidation Processes Fenton, Fenton-Like and Photo-Fenton for Removal of Phenol from Aqueous Solutions. J Chem Soc Pakistan 37, 6.

Neyens, E., \& Baeyens, J. (2003). A Review of Classic Fenton's Peroxidation as an Advanced Oxidation Technique. J Hazard Mater 98, 33-50. 
Primo, O., Rivero, M.J., Ortiz, I. (2008). Photo-Fenton Process as an Efficient Alternative to the Treatment of Landfill Leachates. J Hazard Mater 153, 834-842.

Neyens, E., \& Baeyens, J. (2003). A review of classic Fenton's peroxidation as an advanced oxidation technique, J. Hazard. Mater., 98 (1-3), 33-50, 2003.

Sun, J.H., Shi, S.H., Lee, Y.F., Sun, S.P. (2009). Fenton Oxidative Decolorization of the Azo Dye Direct Blue 15 in Aqueous Solution. Chem Eng J 155, 680-683

Swarnkar, A.K., Kakodiac A.K., Sharma, B.K. (2015). Use of Photo-Fenton Reagent for Photocatalytic Degradation of Reactive Red 45. Int J Adv Res Chem Sci 2, 6.

Xu, X.R., Li, H.B., Wang, W.H., Gu, J.D. (2004) Degradation of Dyes in Aqueous Solutions by the Fenton Process. Chemosphere 57, 595-600

Zhang, J., Chen, S., Zhang, Y., Quan, X., Zhao, H., Zhang, Y. (2014) Reduction of Acute Toxicity and Genotoxicity of Dye Effluent Using Fenton-Coagulation Process. J Hazard Mater 274, 198204. 